\title{
Evaluation of Differential Physiological and Biochemical Response of Sugarcane (Saccharum spp. Complex cv. Co 94012) Parent and Mutant's in Response to Salt Stress
}

\author{
S. S. Gadakh' ${ }^{1 *}$, D. U. Patel ${ }^{2}$ and Y. G. Ban ${ }^{3}$
}

${ }^{1}$ Dept. of Agricultural Botany, College of Agriculture, Nandurbar, Maharashtra, (425 412), India

${ }^{2}$ Main Sugarcane Research Station, Navsari Agricultural University, Navsari, Gujarat 3(96 450) India

${ }^{3}$ Dept. of Agricultural Botany, Mahatma Phule Krishi Vidyapeeth, Rahuri, Maharashta (413 722), India

\section{Corresponding Author}

S. S. Gadakh

e-mail: gadakhsuraj@gmail.com

\author{
Article History \\ Manuscript No. AR1740 \\ Received in $27^{\text {th }}$ November, 2016 \\ Received in revised form $16^{\text {th }}$ May, 2017 \\ Accepted in final form $6^{\text {th }}$ June, 2017
}

\begin{abstract}
The present investigation carried out at Main Sugarcane Research Station, Navsari Agricultural University, Navsari during 2011-2014 to develop salt tolerance lines in sugarcane. Sugarcane mutants against salt tolerance were derived using in vitro mutagenesis and regeneration under $\mathrm{NaCl}$ stress. Sugarcane cv. 94012 was used for callus development from meristimatic leaf whorl on MS medium supplemented with $4 \mathrm{mg} / \mathrm{l}$ 2,4-D+2\% sucrose. At treatment of Ethyl Methane Sulphonate $(0.5 \%)$ for 2 hours treatment $48.60 \%$ calli survived similarly out of four concentration of $\mathrm{NaCl} 100 \mathrm{mM}$ concentration of $\mathrm{NaCl}$ give at least $50.20 \%$ survived of calli. So these concentrations were used for development of salt tolerant mutant in sugarcane. The calli were treated with $\mathrm{EMS}$ lethal dose $\left(\mathrm{LD}_{50}\right)$ placed on shoot regeneration media containing $\mathrm{LD}_{50}$ concentration of $\mathrm{NaCl}$. The plants which regenerated from the tolerant calli were grown in pot culture system under five levels of salinity stress as compared to parental plants (source variety). With increasing supply of $\mathrm{NaCl}$, root growth was more adversely affected. The growth of shoot, Chlorophyll content, photosynthesis rate, stomatal conductance and dry matter showed a decreasing trend but it shows significantly slow rate in tolerant mutants than parental plants. Mutant plants performed significantly well than parental plants in salt stress condition in all physiological and biochemical parameters. The result showed that high salt concentration $\mathrm{Na}^{+}$content in shoot of tolerant mutant and but was less than the normal plant. While, $\mathrm{K}^{+}$content in shoot was high in tolerant mutants than normal plants.
\end{abstract}

Keywords: Sugarcane, salt tolerance, in vitro, calli

\section{Introduction}

Sugarcane is the most important cash crops in India. Improvement in this crop through breeding is handicapped because of the complex flowering behavior under natural day-length conditions in India. The complexity and polygenic nature of salinity tolerance has seriously limited the efforts to develop the salt tolerant crop variety through conventional breeding practices. Tissue and cell culture techniques provide new methods for deriving genetic variation in relatively shorter duration. The use of plant cell culture techniques has expanded greatly particularly in the improvement of vegetatively propagated crops like sugarcane. In this crop genetic variation can be introduced through somaclonal variation (Heinz and Mee, 1960; Liu et al., 1972). It has been reported that in vitro irradiation and other mutagenic agents increase variation and the level of stress tolerance among regenerants (Choudhari et al., 1994). Somaclonal variation in combination with in vitro mutagenesis and selection has been applied for the isolation of agronomically useful mutants in sugarcane (Jain, 2000; Patade et al., 2006; Shomeili et al., 2011; Dalvi et al., 2012; Koch et al., 2012). Sugarcanes are extremely salt sensitive crop and soil salinity is a major constraint in the production of these crops in India. There are 6744 thousand ha of salt affected soil in the India (Anonymous, 2013). Majority of salt affected soils occur in the states of Gujarat, Uttar Pradesh, Maharashtra, Rajasthan and Tamilnadu. Keeping in view this situation, chemical induced mutations coupled with tissue culture based selection protocols were adopted for the development of salt tolerance in these crops. The present study was carried out to determine the effect of chemical mutation and salinity on callus growth and regeneration in sugarcane and growth of micro propagated plants in Sugarcane.

\section{Materials and Methods}

Present study was carried out in the Tissue Culture Laboratory, Main Sugarcane Research Station, Navsari Agricultural University, Navsari during 2011-2014. Healthy young leaf explants including apical meristems were obtained from the 
shoot of commercial sugarcane variety Co 94012.

\subsection{In vitro mutagenesis and screening}

Calli were established from the smaller pieces of explants, made on Murashige and Skoog medium, supplemented with $20 \mathrm{~g} \mathrm{l}^{-1}$ sucrose, $7.5 \mathrm{~g} \mathrm{l}^{-1}$ agar and $4 \mathrm{mg} \mathrm{l}^{-1}$ 2,4-D. The medium was adjusted to $\mathrm{pH} 5.8$ with $\mathrm{NaOH}(0.1 \mathrm{~N})$, autoclaved at 120 ${ }^{\circ} \mathrm{C}$ and $15 \mathrm{lbs}$ psi for $15 \mathrm{~min}$. After 4 weeks, embryogenic calli were separated from the explants and treated with different treatment of EMS (0.5\%) i.e., 0, 1, 2, 3 and 4 hours. Lethal dose $\left(\mathrm{LD}_{50}\right)$ of EMS was decided on the basis of survival per cent of callus. After decide $\mathrm{LD}_{50}$ of EMS callus transferred to MS media supplemented with different levels of $\mathrm{NaCl}(0,50,100$, 150 and $200 \mathrm{mM}$ ) and lethal dose ( $\left.\mathrm{LD}_{50}\right)$ of $\mathrm{NaCl}$ was decided on basis of survival per cent of callus. Salt tolerant plantlets were regenerated from callus treated with EMS $\left(\mathrm{LD}_{50}\right)$ on MS medium supplemented with the $\mathrm{NaCl}\left(\mathrm{LD}_{50}\right)$.

\subsection{Regeneration protocol}

Cultures were grown in sterilize plastic petri-plates closed with paraffin wax strip. Plantlets were regenerated from treated callus and after 3 to 4 weeks of transfer selected healthy plantlets on root induction medium, i.e., $1 / 2 \mathrm{MS}$ medium of the same composition as earlier mentioned, but with special hormones (Patel, 2007) and in a growth chamber under longday conditions (16/8 hours light/dark cycle) at a temperature of $25 \pm 2{ }^{\circ} \mathrm{C}$ and relative humidity of $55 \pm 5 \%$. Light was provided by white fluorescent tubes ( $40 \mathrm{~W}$ ) with approximately 2000 lux/m light intensity. After root formation plantlets were grown in poly-house for primary hardening then shed net for secondary hardening for one month each. The best and healthy plantlets were selected as tolerant mutants for the next evaluations.

\subsection{Evaluation in pot experiment}

Mutants rose from treatment EMS $(0.5 \%)\left(\operatorname{LD}_{50}\right)+\mathrm{NaCl}\left(\operatorname{LD}_{50}\right)$ and Normal plants (somaclones from non-treated callus) were evaluate for salt tolerance in pot culture with five treatment of $\mathrm{NaCl}$ concentrations i.e., 0, 50, 100, 150 and $200 \mathrm{mM}$. So, healthy plant was transferred to pots with $50 \times 30 \mathrm{~cm}^{2}$ (height $\times$ width) specification. Holes were made in the bottom of pots and accommodate one plant pot ${ }^{-1}$. Only $2 / 3$ of the pot filled with the potting mixture i.e., Clay:Sand : FYM (1:1:1) to ensure the presence of adequate air inside the pots. Nutrient solutions were given to plant every 5 days together with addition of the salinity levels. The solution was tested every week to regulate the $\mathrm{pH}$ and $\mathrm{EC}$, and distilled water was added daily to replace transpiration losses.

\subsection{Morphological, physiological and biochemical analysis}

Since the morphological features of the mutant plants were not sufficient, physiological and biochemical analysis was also used as compared to their parental variety. All the observation recorded 60 days after planting of plantlets. All measurements were conducted on five replicate plants per each treatment.

\subsection{Morphological characters}

Total number of green leaves on the plant from each treatment was counted. Leaf area was measured by leaf area meter (Model LI-3000, LI-COR, USA) and expressed as $\mathrm{cm}^{2}$. Shoot length and root length measured of randomly selected plants. Fresh weight (g) and dry weight (g) also recorded. Dry matter accumulation was quantified by obtaining dry weights of plants at $70{ }^{\circ} \mathrm{C}$ for 48 hours in a dry oven.

\subsection{Physiological characters}

The chlorophyll content index was recorded with help of chlorophyll content meter (CCM-200 Plus manufactured by Apogee Instrument). It measures the absorbance of both wavelengths and calculates a Chlorophyll Concentration Index $(\mathrm{CCl})$ value that is proportional to the amount of chlorophyll in the sample of each treatment. The photosynthetic rate, stomatal conductance and transpiration rate were measured using CIRAS-1A photosynthetic system. An open system of narrow rectangular chamber with window was used. Every observation was recorded with leaf covering full window of the system. Observations were made on fully expanded green leaves from $3^{\text {rd }}$ and $4^{\text {th }}$ from top and measured at 8.30 to $10.30 \mathrm{am}$. Each leaf was fully exposed and the open chamber was held at such an angle that the surface of the leaf directly faced the sun.

\subsection{Biochemical characters}

$\mathrm{Na}^{+}$and $\mathrm{K}^{+}$content in shoot were assayed by the procedure earlier reported (Basu et al., 2002). $\mathrm{Na}^{+}$and $\mathrm{K}^{+}$contents of shoot were quantified with an Atomic Absorption Spectrophotometer (GBC 904 AA, GBC Scientific Equipment PTY LTD, Australia) and expressed as $\mu \mathrm{mol} \mathrm{g}^{-1}$ fresh weight

\subsection{Statistical analysis}

The experiment was a factorial experiment of two factors, with five replications and arranged in a Completely Randomized Design. The first factor was sugarcane Normal plants and derived salinity tolerant mutants of variety Co 94012 . The second factor was five salinity levels $(0,50,100,150$ and $200 \mathrm{mM} \mathrm{NaCl}$ ). The data generated from the experiments were subjected to statistical analysis in Factorial Completely Randomized Design (FCRD) whenever, necessary as prescribed by Panse and Sukhatme (1985). Transformation of data was carried out prior to statistical analysis as suggested by Steel and Torrie (1981).

\section{Results and Discussion}

\subsection{In vitro mutagenesis}

The results on survival per cent of callus to different EMS $(0.5 \%)$ treatments are given in Table 1 . Culture exposed to 2 hour treatment almost $50 \%$ survival response compared to control non-treated culture (Table 1). Similar result noticed by Mallikarjun et al. (2008) in sugarcane. Koch et al. (2009) exposed callus to $8 \mathrm{mM}$ and $16 \mathrm{mM}$ EMS for development of tolerant cell.

\subsection{In vitro salinity screening}

The results on survival per cent of callus to different $\mathrm{NaCl}$ 


\begin{tabular}{|c|c|c|c|c|c|c|c|}
\hline \multicolumn{8}{|c|}{$\begin{array}{l}\text { Table 1: Survival per cent of callus after } 30 \text { days to different } \\
\text { EMS }(0.5 \%) \text { treatments to determine lethal dose }\left(\mathrm{LD}_{50}\right) \text { of } \\
\text { EMS }\end{array}$} \\
\hline \multirow[t]{2}{*}{$\begin{array}{l}\text { Geno- } \\
\text { type }\end{array}$} & \multirow[t]{2}{*}{$\begin{array}{c}\text { EMS 0.5\% } \\
\text { (Hour) }\end{array}$} & \multicolumn{6}{|c|}{$\%$ Callus survive } \\
\hline & & 1 & 2 & 3 & 4 & 5 & Mean \\
\hline \multirow{5}{*}{$\begin{array}{l}\text { Co } \\
94012\end{array}$} & 1 & 69 & 70 & 70 & 69 & 70 & 69.60 \\
\hline & 2 & 49 & 48 & 49 & 48 & 49 & 48.60 \\
\hline & 3 & 12 & 12 & 13 & 13 & 13 & 12.60 \\
\hline & 4 & 3 & 3 & 2 & 3 & 3 & 2.80 \\
\hline & 0 (control) & 100 & 100 & 100 & 100 & 100 & 100.00 \\
\hline
\end{tabular}

treatments are given in Table 2. Culture exposed to $100 \mathrm{mM}$ treatment almost $50 \%$ survivals as compared to control nontreated culture (Table 2). Similar results obtained by Patade and Suprasanna (2009) for $171.1 \mathrm{mM}$ and Munir and Aftab (2009) for $120 \mathrm{mM}$ concentration of $\mathrm{NaCl}$. These results are in close agreement with those reported by Mallikarjun et al. (2008); Shomeili et al. (2011); Gandonou et al. (2005b).

Table 2: Survival per cent of callus after 30 days to different treatments of $\mathrm{NaCl}$ to determine lethal dose $\left(\mathrm{LD}_{50}\right)$ of $\mathrm{NaCl}$

\begin{tabular}{lccccccc}
\hline $\begin{array}{l}\text { Geno- } \\
\text { type }\end{array}$ & $\begin{array}{c}\text { Conc. } \\
\text { of } \mathrm{NaCl} \\
(\mathrm{mM})\end{array}$ \\
\hline & 1 & 2 & 3 & 4 & 5 & Mean \\
Co & 50 & 88 & 87 & 88 & 89 & 88 & 88.00 \\
94012 & 100 & 51 & 50 & 49 & 50 & 51 & 50.20 \\
& 150 & 24 & 23 & 22 & 24 & 23 & 23.20 \\
& 200 & 3 & 4 & 3 & 4 & 3 & 3.40 \\
& 0 (control) & 100 & 100 & 100 & 100 & 100 & 100.00 \\
\hline
\end{tabular}

\subsection{Evaluation in pot experiment}

In the treatment $T_{3}$ leaf area of mutant plants $\left(334.9 \mathrm{~cm}^{2}\right)$ was significantly higher as compared normal plants (305.8 $\mathrm{cm}^{2}$ ) (Table 3). Carbon partitioning depends on the strength of both source and sink. As the leaf provides the platform for photosynthesis, leaf area indicates the strength of the source of a crop. Photosynthesis and dry matter production of a plant is proportional to the amount of leaf area on the plant (Padmathilake et al., 2007; Shomeili et al., 2011). There was significantly decrease in number of leaves in treatment $T_{5}$ in mutant plants (5.84) as compared to treatment $\mathrm{T}_{1}$ (7.44) (Table 3). Rapid and transient reductions in leaf expansion rates after a sudden increase in salinity have been recorded in maize (Cramer and Bowman, 1991; Neumann, 1993), rice (Yeo et al., 1991) and wheat and barley (Passioura and Munns, 2000).

Numerous works comparing general responses of some plant species with different salinity levels, reported growth reduction under salt stress conditions (Altman, 2003; Barba et al., 1977;
Jain, 2000; Shomeili et al., 2011). Under this experiment conditions, contrary to the normal plants (Co 94012), shoot length significantly higher in tolerant mutants $(51.98 \mathrm{~cm})$ as compared to normal plants $\left(35.07 \mathrm{~cm}\right.$ ) in treatment $\mathrm{T}_{4}$ (Table 3). Root length was significantly decreased from $50.23 \mathrm{~cm}$ to $24.20 \mathrm{~cm}$ and $50.12 \mathrm{~cm}$ to $20.84 \mathrm{~cm}$ in tolerant mutants and normal plants respectively with increase in salinity concentration. Both root length and shoots length decreased with increase in salt concentration in normal plants but not in the tolerant variant. These results are in agreement with results obtained previously, which also indicated that roots were among the first plant organs affected by salt stress and the most sensitive ones (Bhatnagar et al., 2008). According to Neumann (1993) report, salinity can rapidly inhibit root growth and hence the capacity for uptake of water and essential mineral nutrients from the soil. In culture conditions, tolerant variant kept normal growth at elevated $\mathrm{NaCl}$ concentrations and showed no inhibitory effect on shoot growth.

In present study, at higher salinity level significantly maximum photosynthesis rate $1.54 \mu \mathrm{mol} \mathrm{CO} \mathrm{m} \mathrm{m}^{-2} \mathrm{~s}^{-1}$ was recorded in tolerant mutants as compared to normal plants $(0.83 \mu \mathrm{mol}$ $\mathrm{CO}_{2} \mathrm{~m}^{-2} \mathrm{~s}^{-1}$ ) (Table 4). In tolerant mutants stomatal conductance was significantly decreased from 20.04 to $8.28\left(\mathrm{~mol} \mathrm{CO}_{2} \mathrm{~m}^{-2}\right.$ $\left.\mathrm{s}^{-1}\right)$ and in normal plants stomatal conductance decreased from 20.06 to $6.95\left(\mathrm{~mol} \mathrm{CO}_{2} \mathrm{~m}^{-2} \mathrm{~s}^{-1}\right)$ with increase in salinity level (Table 4). In present investigation it is reported that photosynthesis rate and stomatal conductance reduced with increase in salinity level but, reduction rate was less in tolerant mutants as compared to normal plants. Present finding are in line with Vasantha et al., 2010; Shomeili et al., 2011 in sugarcane. The reasons for reduced photosynthesis include stomatal closure and feedback inhibition due to reduced sink activity. Further, a reduction in stomatal conductance may results from the osmotic effect of salinity.

In tolerant mutants of chlorophyll content index was maximum in treatment $T_{1}(45.20)$ and minimum in $T_{5}$ (42.40) (Table 4). Similarly in normal plants $\mathrm{CCl}$ was maximum in treatment $\mathrm{T}_{1}$ (45.23) and minimum in $T_{5}$ (41.19). Reductions of chlorophyll content under elevated salinity conditions were observed in some salt-sensitive land species (Munns, 2002). In contrast, chlorophyll content in salt tolerant plants either do not decline or rise with increasing salinity (Patade et al., 2006). Chlorophyll concentration can be used as a sensitive indicator of the cellular metabolic state; thus, its decrease signifies toxicity in tissues due to accumulation of ions (Don et al., 2010). The rate of salt accumulation in shoots of salt tolerant plants can be determined by the rate of transpiration. Transpiration rate generally tend to decline with increasing rhizospheric salinity in both sensitive and tolerant plants (Michael et al., 1997; Shomeili et al., 2011). It might be due to salt accumulation in the mesophyll which reduced stomatal aperture (Flowers and Yeo, 1995). Our results showed that the salt tolerant variant have been able to transport lesser harmful salt ions $\left(\mathrm{Na}^{+}\right)$to shoot tissues and then had a higher transpiration than normal 


\begin{tabular}{|c|c|c|c|c|c|c|c|c|}
\hline & Treat. & $\begin{array}{l}\text { Salt conc. } \\
\text { (mM) }\end{array}$ & $\begin{array}{c}\text { Leaf area } \\
\left(\mathrm{cm}^{2}\right)\end{array}$ & $\begin{array}{l}\text { No. of } \\
\text { leaves }\end{array}$ & $\begin{array}{l}\text { Shoot length } \\
(\mathrm{cm})\end{array}$ & $\begin{array}{l}\text { Root length } \\
(\mathrm{cm})\end{array}$ & $\begin{array}{c}\text { Fresh } \\
\text { weight }(\mathrm{g})\end{array}$ & $\begin{array}{c}\text { Dry } \\
\text { weight (g) }\end{array}$ \\
\hline \multirow[t]{5}{*}{ Mutant plants } & $\mathrm{T}_{1}$ & 0 & 359.8 & 7.44 & 88.11 & 50.23 & 35.42 & 12.49 \\
\hline & $\mathrm{T}_{2}$ & 50 & 346.6 & 7.47 & 68.97 & 37.42 & 28.27 & 8.88 \\
\hline & $\mathrm{T}_{3}$ & 100 & 334.9 & 7.17 & 60.51 & 32.38 & 19.96 & 6.88 \\
\hline & $\mathrm{T}_{4}$ & 150 & 326.2 & 6.83 & 51.98 & 29.81 & 15.11 & 5.10 \\
\hline & $\mathrm{T}_{5}$ & 200 & 313.4 & 5.84 & 36.57 & 24.20 & 11.10 & 4.70 \\
\hline \multirow[t]{5}{*}{ Normal plants } & $\mathrm{T}_{1}$ & 0 & 360.2 & 7.48 & 88.23 & 50.12 & 35.00 & 12.61 \\
\hline & $\mathrm{T}_{2}$ & 50 & 340.8 & 7.31 & 61.08 & 35.82 & 18.96 & 7.36 \\
\hline & $T_{3}$ & 100 & 305.8 & 6.53 & 51.55 & 30.13 & 16.52 & 5.95 \\
\hline & $\mathrm{T}_{4}$ & 150 & 282.9 & 6.08 & 35.07 & 24.12 & 10.47 & 4.81 \\
\hline & $\mathrm{T}_{5}$ & 200 & 268.3 & 5.45 & 31.22 & 20.84 & 9.89 & 3.50 \\
\hline \multirow[t]{3}{*}{ SEM \pm} & & M & 0.881 & 0.045 & 0.235 & 0.236 & 0.201 & 0.070 \\
\hline & & $\mathrm{N}$ & 1.394 & 0.071 & 0.371 & 0.373 & 0.318 & 0.110 \\
\hline & & $M \times N$ & 1.971 & 0.101 & 0.525 & 0.528 & 0.450 & 0.156 \\
\hline \multirow[t]{3}{*}{$\mathrm{CD}(p=0.05)$} & & M & 2.618 & 0.134 & 0.697 & 0.701 & 0.597 & 0.207 \\
\hline & & $\mathrm{N}$ & 4.139 & 0.212 & 1.102 & 1.109 & 0.944 & 0.328 \\
\hline & & $M \times N$ & 5.854 & 0.300 & 1.558 & 1.568 & 1.336 & 0.463 \\
\hline CV \% & & & 1.217 & 2.992 & 1.830 & 3.151 & 4.482 & 4.319 \\
\hline
\end{tabular}

Mutant plants (M): in vitro screened tolerant mutant plant; Normal plants (N): Normal plants of variety

Table 4: Physiological response of sugarcane mutants (cv. Co 94012) to salt stress in pot culture

\begin{tabular}{lcccccccc}
\hline & Treat. & $\begin{array}{c}\text { Salt conc. } \\
(\mathrm{mM})\end{array}$ & $\begin{array}{c}\text { Chloro- } \\
\text { phyll con- } \\
\text { tent Index }\end{array}$ & $\begin{array}{c}\text { Photosynthe- } \\
\text { sis rate }(\mu \mathrm{mol} \\
\left.\mathrm{CO}_{2} \mathrm{~m}^{-2} \mathrm{~s}^{-1}\right)\end{array}$ & $\begin{array}{c}\text { Stomatal con- } \\
\text { ductance }(\mathrm{mol} \\
\left.\mathrm{CO}_{2} \mathrm{~m}^{-2} \mathrm{~s}^{-1}\right)\end{array}$ & $\begin{array}{c}\text { Transpiration } \\
\text { rate }(\mathrm{m} \mathrm{mol} \\
\left.\mathrm{H}_{2} \mathrm{O} \mathrm{m}^{-2} \mathrm{~s}^{-1}\right)\end{array}$ & $\begin{array}{c}\mathrm{K}+(\mu \mathrm{mol} \\
\left.\mathrm{g}^{-1} \mathrm{FW}\right)\end{array}$ & $\begin{array}{c}\mathrm{Na}+(\mu \mathrm{mol} \\
\left.\mathrm{g}^{-1} \mathrm{FW}\right)\end{array}$ \\
\hline Mutant plants & $\mathrm{T}_{1}$ & 0 & 359.8 & 7.44 & 88.11 & 50.23 & 35.42 & 12.49 \\
& $\mathrm{~T}_{2}$ & 50 & 346.6 & 7.47 & 68.97 & 37.42 & 28.27 & 8.88 \\
& $\mathrm{~T}_{3}$ & 100 & 334.9 & 7.17 & 60.51 & 32.38 & 19.96 & 6.88 \\
& $\mathrm{~T}_{4}$ & 150 & 326.2 & 6.83 & 51.98 & 29.81 & 15.11 & 5.10 \\
& $\mathrm{~T}_{5}$ & 200 & 313.4 & 5.84 & 36.57 & 24.20 & 11.10 & 4.70 \\
Normal plants & $\mathrm{T}_{1}$ & 0 & 360.2 & 7.48 & 88.23 & 50.12 & 35.00 & 12.61 \\
& $\mathrm{~T}_{2}$ & 50 & 340.8 & 7.31 & 61.08 & 35.82 & 18.96 & 7.36 \\
& $\mathrm{~T}_{3}$ & 100 & 305.8 & 6.53 & 51.55 & 30.13 & 16.52 & 5.95 \\
& $\mathrm{~T}_{4}$ & 150 & 282.9 & 6.08 & 35.07 & 24.12 & 10.47 & 4.81 \\
SEM \pm & $\mathrm{T}_{5}$ & 200 & 268.3 & 5.45 & 31.22 & 20.84 & 9.89 & 3.50 \\
& & $\mathrm{M}$ & 0.881 & 0.045 & 0.235 & 0.236 & 0.201 & 0.070 \\
& & $\mathrm{~N}$ & 1.394 & 0.071 & 0.371 & 0.373 & 0.318 & 0.110 \\
$\mathrm{CD}(p=0.05)$ & & $\mathrm{M} \times \mathrm{N}$ & 1.971 & 0.101 & 0.525 & 0.528 & 0.450 & 0.156 \\
& & $\mathrm{M}$ & 2.618 & 0.134 & 0.697 & 0.701 & 0.597 & 0.207 \\
& & $\mathrm{~N}$ & 4.139 & 0.212 & 1.102 & 1.109 & 0.944 & 0.328 \\
& & $\mathrm{M} \times \mathrm{N}$ & 5.854 & 0.300 & 1.558 & 1.568 & 1.336 & 0.463 \\
& & 1.217 & 2.992 & 1.830 & 3.151 & 4.482 & 4.319 \\
\hline
\end{tabular}

Mutant plants (M): in vitro screened tolerant mutant plant; Normal plants (N): Normal plants of variety 
plants. Sodium and chloride concentration in shoots and roots of sugarcane differently increased with salinity genotypically (Patade et al., 2006; Karpe et al., 2012).

Under salinity stress, results showed that total dry matter production highly correlated with $\mathrm{K}^{+}$and $\mathrm{Na}^{+}$(Table 1 and 2). The $\mathrm{Na}^{+}$content in shoot was significantly higher in normal plants $\left(3.15 \mu \mathrm{mol} \mathrm{g}^{-1} \mathrm{FW}\right)$ as compared to tolerant mutants $\left(1.96 \mu \mathrm{mol} \mathrm{g}^{-1} \mathrm{FW}\right)$ at highest salinity level (Table 4). It was indicated that higher amounts of $\mathrm{Na}^{+}$in plant tissues significantly reduced dry matter production. Similar results reported by Patade et al. (2008). In the absence of stress, $\mathrm{K}^{+}$ concentration showed a non-significant difference among the two experimental plant types. But with increased in salinity, it changed adversely and sharply in tolerant variant though, this was lower in normal plants than tolerant mutants. Results showed that, high correlation between dry weight and $\mathrm{K}^{+}$at all salinity levels (Table 1 and 2). These findings are in contrast with some previous results of (Patade et al., 2006; Wahid et al., 2006) and are in agreement with others (Gandonau et al., 2008; Shomeili et al., 2011; Karpe et al., 2012).

With increasing salt concentrations, total dry weight decreased sharply in normal plants than new tolerant variant. At highest salinity level significantly maximum dry weight was recorded in tolerant mutants ( $\left.4.70 \mathrm{~g} \mathrm{plant}^{-1}\right)$ as compared to normal plants ( $3.50 \mathrm{~g} \mathrm{plant}^{-1}$ ) (Table 3 ). The decrease in value of the dry weight at high $\mathrm{NaCl}$ concentrations indicates that plantlets were affected positively by salinity, especially in normal plants of variety.

Salinity still remains the major abiotic stresses that limit and pose a threat to agricultural production in many parts of the world (Altman, 2003; Don et al., 2010). While, numbers of mechanisms relating to improved stress adaptation in crops have been suggested, the fact remains that their association with genetic gains for yield and their relative importance in different salinity-prone environments are still only partially defined. Therefore, a well-focused approach combining the molecular, physiological and metabolic aspect of abiotic stress tolerance is required (Bhatnagar et al., 2008).

\section{Conclusion}

In vitro mutagenesis with selection techniques can be used to generate salt-tolerant plant lines in sugarcane and also to study physiological and biochemical indicators of salinity tolerance in this plant. Salt tolerance seems to be related to the efficiency of a tissue to absorb, deposit and transport the levels of inorganic solutes in response to salt stress. The results indicated that, the physiological parameters have a positive role to play in tolerance of salinity by the generated plant.

\section{Acknowledgement}

The authors wish to thanks to Head, Department of Plant Molecular Biology and Biotechnology, Navasari Agricultural University, Navsari for providing laboratory facility at the division during course of this investigation.

\section{References}

Altman, A., 2003. From plant tissue culture to biotechnology: Scientific revolution, biotic stress tolerance and forestry. In vitro Cellular and Developmental Biology Plant 39, 75-84.

Anonymous, 2013. Extent and Distribution of salt affected soil in India. www.cssri.org.

Barba, R.C., Zamora, A.B., Mallion, A.K., Linga, C.K., 1977. Sugarcane tissue culture research. In: Proceedings of the international society of sugarcane technologist's congress. Sao Paolo, Brazil 16, 1843-1864.

Basu, S., Gangopadhaya, G., Mukharjee, B.B., 2002. Salt tolerance in rice in vitro implications of accumulation of $\mathrm{Na}^{+}, \mathrm{K}^{+}$and proline. Plant Cell, Tissue and Organ Culture 69, 55-64.

Bhatnagar, M.P., Vadez, V., Sharma, K.K., 2008. Transgenic approaches for abiotic stress tolerance in plants: retrospect and prospects. Plant Cell Replication 27, 411-424.

Chaudhary, M.T., Wainwright, S.J., Merrett M.J., Shah, M., 1994. Salt tolerant of Lucerne (Medicago media Pers.) regenerated from salt-selected suspension cultures. Plant Science 98, 97-102.

Cramer, G.R., Bowman, D.C., 1991. Kinetics of maize leaf elongation. Increased yield threshold limits short-term, steady-state elongation rates after exposure to salinity. Journal of Experimental Botany 42, 1417-1426.

Dalvi, S.G., Vasekar, V.C., Yadav, A, Tawar, P.N., Dixit, G.B., Theerthaprasad, D., Deshmukh, R.B., 2012. Screening of Promising Sugarcane Somaclones for Agronomic Traits, and Smut Resistance Using PCR Amplification of Inter Transcribed Region (ITS) of Sporisorium scitaminae. Sugar Tech 14(1), 68-75.

Don, K.K.G., Xia, Y.P., Zhu, Z., Le, C., Wijeratne, A.W., 2010. Some deleterious effects of long-term salt stress on growth, nutrition, and physiology of gerbera (Gerbera jamesonii L.) and potential indicators of its salt tolerance. Journal of Plant Nutrition 33, 2010-2027.

Flowers, T.J., Yeo, A.R., 1995. Breeding for salinity resistance in crop plants; what the next? Australian Journal of Plant Physiology 22, 875-884.

Gandonou, C.B., Agbangla, C., Ahanhanzo, C, Errabii, T., Idaomar, M., Abrini, J., Senhaji, N.S., 2008. In vitro culture techniques as a tool of sugarcane bud germination study under salt stress. African Jornal of Biotechnology 7(20), 3677-3679.

Gandonou, C., Abrini, J., Idaomar, M., SkaliSenhaji, N., 2005b. Effects of $\mathrm{NaCl}$ on growth and ion and proline accumulation in sugarcane (Saccharum sp.) callus culture. Belgian Journal of Botany 138, 173-180.

Heinz, D.J., Mee, G.W.P., 1969. Plant differentiation from callus tissue of Saccharum species. Crop Science 9, 346-348.

Jain, S.M., 2000. Tissue culture-derived variation in crop improvement. Euphytica 118, 153-166. 
Mallikarjun Kanganal, M., Hanchinal, R.R., Nadaf, H.L., 2008. Ethyl methane sulphonate (EMS) induced mutation and selection for salt tolerance in sugarcane in vitro. Indian Journal of Plant Physiology 13(4), 405-410.

Karpe, A., Nikam, A.A., Chimote, K.P., Kalwade, S.B., Kawar, P.G., Babu, H., Devarumath, R.M., Suprasanna, P., 2012. Differential responses to salinity stress of two varieties (CoC 671 and Co 86032) of sugarcane (Saccharum Officinarum L.). African Journal of Biotechnology 11(37), 9028-9035.

Koch, A.C., Ramgareeb, S., Rutherford, R.S. Snyman, S.J., Watt, M.P., 2012. An in vitro mutagenesis protocol for the production of sugarcane tolerant to the herbicide imazapyr. In vitro Cellular and Developmental Biology Plant 48, 417-427.

Koch, A.C., Ramgareeb, S., Snyman, S.J., Watt, M.P., Rutherford R.S., 2009. Pursuing herbicide tolerance in sugarcane: screening germplasm and induction through mutagenesis. Proceeding of South African Sugarcane Technol. Association 82, 629-632.

Liu, M.C., Huang, Y.J., Shffl, S.C., 1972. The in vitro production of plants from several tissues of Saccharum species. Journal of the Agricultural Association of China 77, 52-58.

Michael, R., Anne-Alineor, V., Dale, S., Mansfield, T.A., 1997. How can stomata contribute to salt tolerance? Annals of Botany 80, 387-393.

Munir, N., Aftab, F., 2009. The role of polyethylene glycol (PEG) pre-treatment in improving sugarcane salt $(\mathrm{NaCl})$ tolerance. Turkish Journal of Botany 33, 407-415.

Munns, R., 2002. Comparative Physiology of Salt and Water Stress. Plant Cell and Environment 28, 239-250.

Neumann, P.M., 1993. Rapid and reversible modifications of extension capacity of cell walls in elongating maize leaf tissues responding to root addition and removal of $\mathrm{NaCl}$. Plant, Cell and Environment 16(9), 1107-1114.

Padmathilake, K.R.E., Wickramaarachchi, V.N., Anver, M.A.M.S., Bandara, D.C., 2007. Biological and Economical Feasibility of Growing Mint (Mentha sylvestris), Mustard (Brassica integrifolia) and Asamodagam (Trachyspermum involucratum) under Hydroponics. Tropical Agricultural Research 19, 193-201.
Panse, V.G., Sukhatme, P.V., 1985. Statistical methods for agricultural workers. $4^{\text {th }}$ (edn.) I.C.A.R., New Delhi.

Passioura, J.B., Munns, R., 2000. Rapid environmental that affect leaf water status induce transient surges or pauses in leaf expansion rate. Australian Journal of Plant Physiology 27, 941-948.

Patade, V.Y., Suprasanna, P., 2009. An in vitro radiation induced mutagenesis-selection system for salinity tolerance in sugarcane. Sugar Tech, 11(3), 246-251.

Patade, V.Y., Suprasanna, P., Bapat, V.A., 2006. Selection for abiotic (salinity and drought) stress tolerance and molecular characterization of tolerant lines in sugarcane. B.A.R.C. Newsletter, 273.

Patade, V.Y., Suprasanna, P., Bapat, V.A., 2008. Gamma irradiation of embryogenic callus cultures and in vitro selection for salt tolerance in sugarcane (Saccharum officinarum L.). Agricultural Science in China 7, 11471152.

Patel, S.R., 2007. Induction of variability through callus culture in sugarcane (Saccharum oficinarum L.) variety CoN 95132. Ph.D. thesis submitted to N.A.U., Navsari.

Shah, R., 2001. Effect of salinity in Indian Agriculture. http:// www.counterview.net/

Shomeili, M., Majid, N., Mosa, M., Rajabi, M., 2011. Evaluation of sugarcane (Saccharum officinarum L.) somaclonal varients tolerance to salinity in vitro and in vivo cultures. African Journal of Biotechnology 10(46), 9337-9343.

Steel, R.G.D., Torrie, J.H., 1981. In: Principles and procedures of statistics. McGraw Hill International Book Company, London $2^{\text {nd }}($ edn.).

Vasantha, S., Venkataramana, S., Gururajarao, P.N., Gomathi, R., 2010. Long term salinity effect on growth, photosynthesis and osmotic characteristics in sugarcane. Sugar tech 12(1), 5-8.

Wahid, A., Ghazanfar, A., 2006. Possible involvement of some secondary metabolites in salt tolerance of sugarcane. Journal of Plant Physiology 163, 723-730.

Yeo, A.R., Lee, K.S., Izard, P., Boursier, P.J., Flowers, T.J., 1991. Short and long-term effects of salinity on leaf growth in rice (Oryza sativa L.). Journal of Experimental Botany 42, 881-889. 